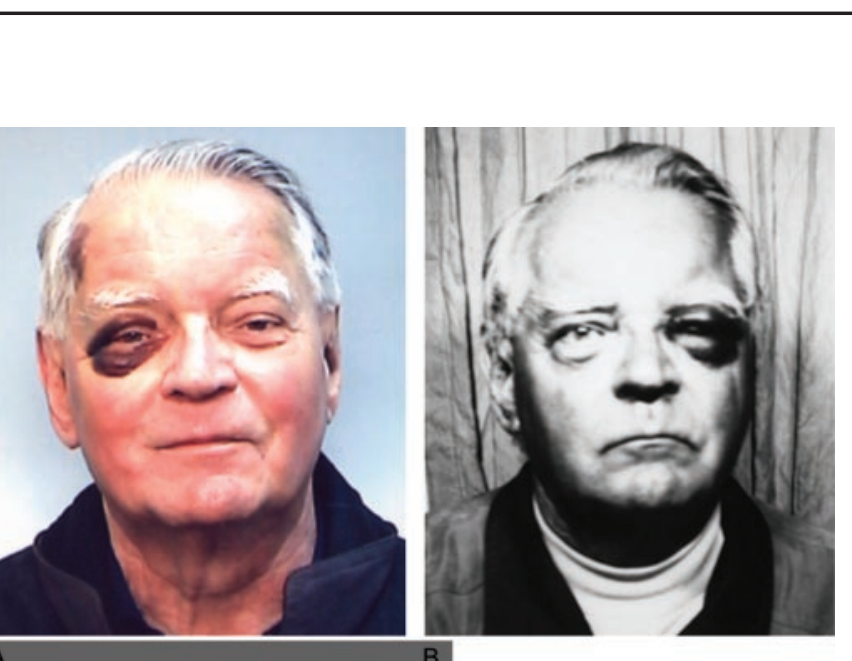

Figure 1. Temporal skull contusions and orbital hematomas after syncopes.

\section{VIDEo Syncope during EEG recording}

Beat Schaer, MD; Stefan Osswald, MD; Peter Fuhr, MD; and David Leppert, MD, Basel, Switzerland

A 75-year-old man had several syncopes with severe skull contusions (figure 1). These events were not preceded by vegetative symptoms such as nausea, dizziness, or palpitations. Holter-EKG was normal and an EEG was performed for suspected epilepsy, during which complete atrioventricular block without ventricular escape-rhythm occurred (figure 2A). Six seconds later, the EEG showed progressive slowing of background activity and voltage reduction, followed by electrocerebral silence (figure $2 \mathrm{~B}$ ); clinically the patient lost cervical muscle tone and became unconscious. Thirty-three seconds later, sinus-rhythm reoccurred, followed by the return of cerebral activity in reverse manner (figure $2 \mathrm{C}$ ). The patient regained consciousness instantly and, when addressed by the technician, he was fully responsive (see video clip). A pacemaker was implanted and the patient was free of symptoms.

Clinical presentation of syncope does not often allow one to distinguish between cerebrovascular and epileptic origin. Despite normal 24-hour EKG, simultaneous EKG recording is mandatory when EEG is used in the evaluation of syncope..$^{1,2}$

1. Pitney MR, Beran RG, Jones A. A simultaneous electrocardiogram is important when electroencephalography is used in the evaluation of loss of consciousness. Electroencephal Clin Neurophysiol 1994;90:246-248.

2. Brenner RP. Electroencephalography in syncope. J Clin Neurophysiol 1997;14:197-209.

Address correspondence and reprint requests to Dr. Beat Schaer, Department of Cardiology, University Hospital, CH-4031 Basel, Switzerland; e-mail: bschaer@uhbs.ch

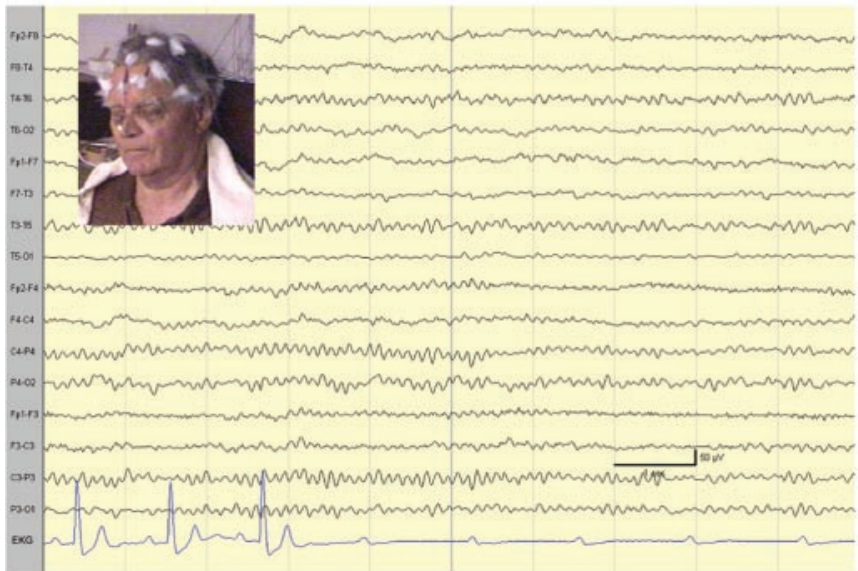

A

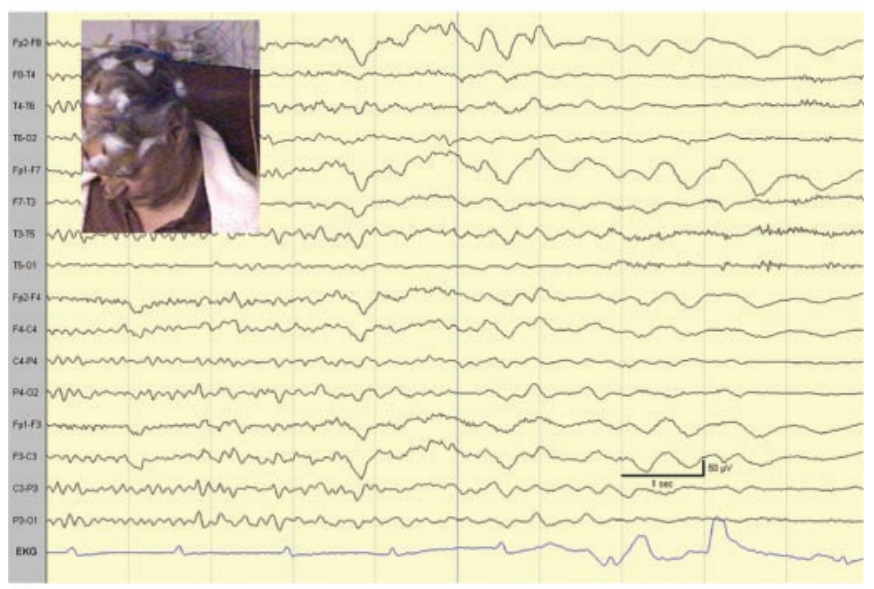

B

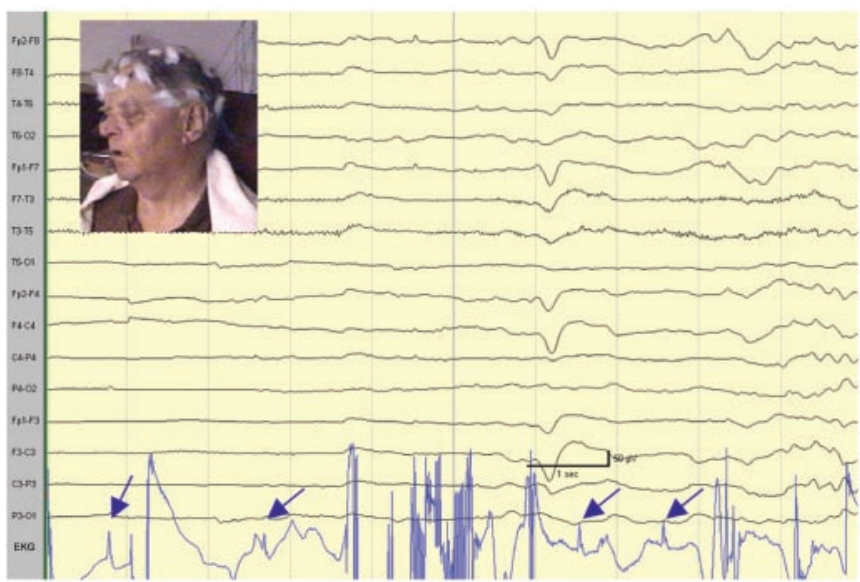

C

Figure 2. (A) Complete AV-block without ventricular escape rhythm during EEG. (B) EEG showing diffuse slowing and finally electrocerebral silence. (C) Reappearance of ventricular escape rhythm (arrows) and of background activity 7 seconds later. QRS complexes indicated by arrows. 


\section{Neurology}

Syncope during EEG recording

Beat Schaer, Stefan Osswald, Peter Fuhr, et al.

Neurology 2004;63;E11

DOI 10.1212/01.WNL.0000137025.35912.1C

This information is current as of September 13, 2004

\section{Updated Information \&}

Services

Supplementary Material

\section{References}

Subspecialty Collections

Permissions \& Licensing

Reprints including high resolution figures, can be found at:

http://n.neurology.org/content/63/5/E11.full

Supplementary material can be found at:

http://n.neurology.org/content/suppl/2004/09/13/63.5.E11.DC2 http://n.neurology.org/content/supp1/2004/09/20/63.5.E11.DC1

This article cites 2 articles, 0 of which you can access for free at: http://n.neurology.org/content/63/5/E11.full\#ref-list-1

This article, along with others on similar topics, appears in the following collection(s):

All Epilepsy/Seizures

http://n.neurology.org/cgi/collection/all_epilepsy_seizures

EEG; see Epilepsy/Seizures

http://n.neurology.org/cgi/collection/eeg_see_epilepsy-seizures

Syncope

http://n.neurology.org/cgi/collection/syncope

Information about reproducing this article in parts (figures,tables) or in its entirety can be found online at:

http://www.neurology.org/about/about_the_journal\#permissions

Information about ordering reprints can be found online:

http://n.neurology.org/subscribers/advertise

Neurology ${ }^{\circledR}$ is the official journal of the American Academy of Neurology. Published continuously since 1951, it is now a weekly with 48 issues per year. Copyright . All rights reserved. Print ISSN: 0028-3878. Online ISSN: 1526-632X.

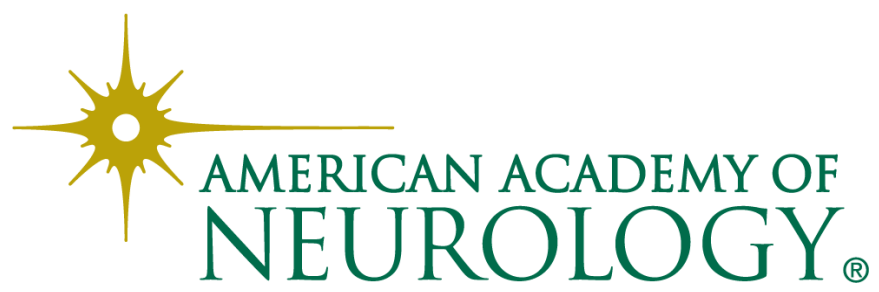

